\title{
The effect of the progressive muscle relaxation combined withs lavender aromatherapy on insomnia of hemodialysis patients
}

\author{
Ida Rosdiana, Yanti Cahyati \\ Department of Nursing. Poltekkes Kemenkes Tasikmalaya. West Java. Indonesia
}

Como citar este artículo:

Rosdiana I, Cahyati I. The effect of the progressive muscle relaxation combined withs lavender aromatherapy on insomnia of hemodialysis patients. Enferm Nefrol. 2021 Ene-Mar;24(1):39-46

\begin{abstract}
Introduction: Insomnia is the much common sleep disorder in hemodialysis patients, which will cause a decrease in quality of life. Aromatherapy combined with progressive muscle relaxation are expected to increase the effects of relaxation on the patient so that the patient's sleep quality can improve optimally.
\end{abstract}

Objective: The study aimed to investigate the effect of the progressive muscle relaxation combined with lavender aromatherapy on insomnia among patients undergoing hemodialysis.

Material and Methods: The design of this study included a quasi-experiment with a pretest-posttest control group approach. The sample selection was performed using a consecutive sampling technique and involved 50 respondents, divided into two equal control and study group. Patients in study group recommended to do progressive muscle relaxation at least four times per week for three weeks and were told to drop two - three drops lavender aromatherapy on a pillow 30 minutes before bedtime at least 4 nights per week for three weeks. The control group recommended to do muscle relaxation and daily routine care at least four times per week for three weeks.

\section{Correspondencia: \\ Yanti Cahyati \\ E-mail: yantinaufal@gmail.com}

Results: The results showed that both study and control groups were equal in terms of demographics, and scores of insomnia at the baseline. There no significant difference between the mean insomnia scores of two group before intervention, while the difference was statistically significant after the intervention. The mean insomnia scores were lower in study group than in the control group.

Conclusion: Progressive muscle relaxation and lavender aromatherapy were effective in decreasing insomnia scores among patients undergoing hemodialysis.

KEYWORDS: insomnia; hemodialysis patients; progressive muscle relaxation; aromatherapy.

\section{El efecto de la relajación muscular progresiva combinado con la aromaterapia de lavanda sobre el insomnio de los pacientes en hemodiálisis}

\section{Resumen}

Introducción: El insomnio es el trastorno del sueño más común en los pacientes en hemodiálisis, que provoca una disminución de la calidad de vida. Se espera que la aromaterapia combinada con relajación muscular progresiva aumente los efectos de la relajación en el paciente para que así la calidad del sueño del paciente pueda mejorar de manera óptima.

Objetivo: Investigar el efecto de la relajación muscular progresiva combinada con aromaterapia de lavanda sobre el insomnio en pacientes sometidos a hemodiálisis. 
Material y Método: Se utilizó un diseño pretest y posttest cuasi-experimental con grupo de control. La selección de la muestra se realizó mediante una técnica de muestreo consecutivo e involucró a 50 encuestados, divididos en dos grupos iguales. Al grupo de estudio se le recomendó hacer relajación muscular progresiva al menos cuatro veces por semana durante tres semanas y que pusieran dos o tres gotas de aromaterapia de lavanda en una almohada 30 minutos antes de acostarse al menos cuatro noches por semana durante tres semanas. Al grupo control se le recomendó realizar relajación muscular y cuidados diarios rutinarios al menos cuatro veces por semana durante tres semanas.

Resultados: Los grupos de estudio y control fueron iguales en términos demográficos y puntuaciones de insomnio al inicio del estudio. No hubo diferencias significativas entre las puntuaciones medias de insomnio para los dos grupos antes de la intervención, mientras que la diferencia fue estadísticamente significativa tras la intervención. Las puntuaciones medias de insomnio fueron más bajas en el grupo de estudio que en el grupo de control.

Conclusión: La relajación muscular progresiva y la aromaterapia de lavanda fueron efectivas para disminuir las puntuaciones de insomnio entre los pacientes sometidos a hemodiálisis.

KEYWORDS: insomnio; pacientes en hemodiálisis; relajación muscular progresiva; aromaterapia.

\section{Introduction}

The prevalence of insomnia in hemodialysis patients ranges from $45 \%$ to $69.1^{1}$. This data varies greatly due to difference in definition, diagnosis, population characteristics, and research methodology. Insomnia is defined as the subjective sensation of short and dissatisfied ${ }^{2}$, while Indonesia Center for Sustainable Development-2 (ICSD-2) defines insomnia as difficulty in starting sleep, waking up too early, often waking up with difficulty falling asleep again and experiencing the consequences of the day due to difficulty sleeping at night $^{3}$.

Difficulty maintaining sleep and not getting enough sleep can result in a patient waking up before he gets enough sleep. This situation generates the patient to experience several consequences, including daytime drowsiness, depressed mood, lack of energy, cognitive impairment, memory disorders, irritability, psychomotor dysfunction and decreased alertness and concentration ${ }^{4}$. In the end, insomnia experienced by kidney failure patients undergoing hemodialysis will cause a decrease in quality of life that has a positive correlation with patient survival, so that proper management is needed according to the factors that influence it ${ }^{5,6}$.

Several pharmacological and non-pharmacological therapies can be used to treat sleep disorders in hemodialysis patients. Pharmacological treatment of insomnia includes therapy sedative-hypnotic which is a group of the central nervous system (CNS) depressants. The therapeutic effect depends on the dose, ranging from mild which causes drowsiness, sleep, to a severe loss of consciousness, Nianaesthesia, coma, and death, so its use must be done with caution. Non-pharmacological interventions have been shown to provide reliable and long-lasting clinical benefits in the treatment of primary insomnia, insomnia in the elderly, and insomnia associated with medical or psychiatric conditions. Therefore, nonpharmacological interventions recommended to be the first line in the management of insomnia ${ }^{7}$. The reason for the improve sleep quality of patients after progressive muscle relaxation (PMR) training may be associated with the balance between the anterior and hypothalamic nucleus. The side effects of stress and anxiety can be prevented by reducing the activity of the sympathetic nervous system and physical and mental relaxation ${ }^{8}$.

Several studies show the benefits of muscle relaxation therapy to improve sleep quality of patients, including research from Saeedi et al. ${ }^{9}$ who found that PMR can improve sleep quality of patients undergoing hemodialysis so that the therapy is stated as a method which is beneficial in improving the sleep quality of HD patients. Besides Amini et al. ${ }^{10}$ research on the effect of progressive muscle relaxation and aerobic movements on anxiety, insomnia, and fatigue in patients with chronic renal failure undergoing hemodialysis. The results of the study showed that PMR can reduce anxiety levels and PMR and aerobics can significantly improve the sleep quality of hemodialysis patients. The results also showed that PMR had a better effect on symptoms of anxiety, sleep disturbance, and fatigue in hemodialysis patients compared to aerobic.

Besides PMR, other non-pharmacological therapies that can be used to treat sleep disorders are aromatherapy. Aromatherapy is a method of nursing therapy that uses volatile plant liquid ingredients or known as essential oils that aim to affect one's mood or 
health ${ }^{11}$. Chien et al..$^{12}$ conducted a study on the effect of lavender aromatherapy on the autonomic nervous system in women with insomnia and the results showed a significant improvement in sleep quality in insomnia women after aromatherapy intervention. Aromatherapy actions combined with PMR are expected to increase the effects of relaxation on the patient so that the patient's sleep quality can improve optimally. This study aims to determine the effect of the progressive muscle relaxation (PMR) and lavender aromatherapy on insomnia undergone by hemodialysis patients.

\section{Material and Method}

\section{- Design and Participants}

This study used a quasi-experimental design with a pretest-posttest approach with a control group. The researcher applied for a research permit and ethical test to The Ethics Committee with ethical clearance No. 2018/KEPK/PE/IX/0035. Respondents consisted of 26 patients in the intervention group that were given PMR and lavender aromatherapy intervention and 26 patients in the control group that were only given PMR intervention, but one respondent from each group resigned from the study so that the total number of respondents was 50 patients. The inclusion criteria of this study were: age 20-60 years, without communication barrier and provided informed consent, willing to participate in the study, having undergone hemodialysis 2 times a week, not described sleep medication therapy and have no history of hospitalization due to psychiatric disorders. Exclusion criteria include patients with a history of allergies and acute respiratory disease.

\section{- Insomnia Severity Index}

Insomnia Severity Index (ISI) is a reliable and valid instrument to quantify perceived insomnia. The validity and reliability of these instruments were reported by several researchers ${ }^{13,14}$. The reliability was calculated by internal consistency. Cronbach's alpha coefficient was reported to be 0.77 and the correlation coefficient was 0.30 to $0.75^{13}$. The contain has seven questions which demonstrate following inpatient issues: the severity of their problem with falling asleep, staying asleep, waking up too early, satisfaction with their current sleep pattern, how much the patients' sleep problems are noticeable to others, how much the patients are worried about their current sleep problem and whether these problems influence their daily functioning. Each question score ranged from 0 to 4 . The seven answers are added up to get a total score. A higher score indicates severe insomnia. Participants completed the questionnaire before and after the intervention.

\section{- Data collections}

The patient's age, gender, levels of education, work status, marital status were collected by sociodemographics questionnaire. Insomnia score measurements were carried out using Insomnia Severity Index. Before starting the study, the researchers provided an oral and written explanation of the goals and methods. All participants were fully included in the study with personal consent, were free to leave the study at any time, and ensured that the data collected was confidential, so the names of the participants were not listed in the results.

\section{- Intervention}

Before the intervention the questionnaires were collected from the experimental and control groups, then patients were taught PMR exercise until they were able to do PMR independently. The researchers instructed the respondents (both control and study group) on how to relax using PMR techniques. The patients must be in relaxed position, and then they instructed to contracting and relaxing a group of muscle in sequence, start with the muscle of the hands, upper arm, forearm, forehead, face, jaw, neck, chest, shoulder, upper back, abdomen, thigh, and calves. Muscle contraction is carried out 5-10 seconds and relaxation for about 5-10 seconds. At the same time, the patient must take a deep breath, inhales through his nose, exhales through his mouth and should be focus on feelings they experience at any stage after relaxing the muscle. The patient's attention is directed to being able to feel the difference between when muscles are contracted and when they are relaxed. This procedure is usually performed for 10 to 20 minutes.

After determining that they had learned how to relax, an educational pamphlet, PMR procedure guidelines and observation sheet were given to the respondents. They were asked to do the performed PMR technique at least 4 times a week for 3 weeks. In addition, study group were given aromatherapy which must be used at least four nights a week for three weeks, by dropping two-three drops of lavender aromatherapy on a pillow at least 30 minutes before bedtime. Patients in the control group received PMR techniques and daily routine care during this period. Monitoring the implementation of interventions at home are carried out by the patient's family members and researcher assistants, as well as the use of observation sheets. The insomnia scores of the two groups were measured after the three weeks intervention. 


\section{- Statistical Analysis}

To analyse the data, SPSS 16 statistical software was used. To report the demographic properties of the data, descriptive statistics were utilized. In order to determine the effect of progressive muscle relaxation and lavender aromatherapy on the score of insomnia, t-test was used.

\section{Results}

In this study, 50 subjects were examined in 2 groups: experimental $(n=25)$ and control $(n=25)$. There was no statistically significant difference between the 2 groups in terms of demographic characteristics (Table 1). There was a significant difference in the mean scores of insomnia between before and after intervention in the experimental and control groups.

Table 1. Characteristics of Respondents in the Control and Treatment Group $(\mathrm{N}=50)$.

\begin{tabular}{|c|c|c|c|c|}
\hline Variables & \multicolumn{2}{|c|}{ Control $(n=25)$} & \multicolumn{2}{|c|}{ Intervention $(n=25)$} \\
\hline Age (years, mean \pm SD) & & & & \\
\hline $\begin{array}{l}\text { Gender }(\mathbf{n}, \%) \\
\text { Male } \\
\text { Female }\end{array}$ & $\begin{array}{l}11 \\
14\end{array}$ & $\begin{array}{l}44 \\
56\end{array}$ & $\begin{array}{l}11 \\
14\end{array}$ & $\begin{array}{l}44 \\
56\end{array}$ \\
\hline $\begin{array}{l}\text { Education level (n,\%) } \\
\text { Higher } \\
\text { Secondary } \\
\text { Low }\end{array}$ & $\begin{array}{c}3 \\
15 \\
7\end{array}$ & $\begin{array}{l}12 \\
60 \\
28\end{array}$ & $\begin{array}{c}5 \\
13 \\
7\end{array}$ & $\begin{array}{l}20 \\
52 \\
28\end{array}$ \\
\hline $\begin{array}{l}\text { Work Status }(\mathbf{n}, \%) \\
\text { Work } \\
\text { Not Working }\end{array}$ & $\begin{array}{c}3 \\
22\end{array}$ & $\begin{array}{l}12 \\
88\end{array}$ & $\begin{array}{c}5 \\
20\end{array}$ & $\begin{array}{l}20 \\
80\end{array}$ \\
\hline $\begin{array}{l}\text { Marriage Status }(\mathbf{n}, \%) \\
\text { Married } \\
\text { Not Married }\end{array}$ & $\begin{array}{c}22 \\
3\end{array}$ & $\begin{array}{l}88 \\
12\end{array}$ & $\begin{array}{c}24 \\
1\end{array}$ & $\begin{array}{c}96 \\
4\end{array}$ \\
\hline
\end{tabular}

Table 2. Insomnia Score Before and After Intervention ( $n=50)$.

\begin{tabular}{lccccc}
\hline Insomnia & Mean & \multicolumn{5}{c}{ SD } & SE & P-Value & N \\
\cline { 3 - 6 } & \multicolumn{5}{c}{ Control Group } \\
Before & 12.52 & 3.732 & 0.746 & 0.001 & 25 \\
After & 10.12 & 3.811 & 0.762 & & \\
\hline \multicolumn{5}{c}{ Intervention Group } \\
\hline Before & 15.4 & 4.509 & 0.902 & 0.000 & 25 \\
After & 7.68 & 4.318 & 0.864 & & \\
\hline
\end{tabular}

in the elderly may be due to a partial decrease in the functioning of the sleep control system as well as the presence of comorbidities which are also a significant contributor to the increased prevalence of insomnia in the elderly ${ }^{16}$. The results of this study are in line with the research of Merlino et al. ${ }^{17}$ which states that the age variable is an independent and significant predictor of sleep disorders in ESRD (patients end-stage renal diseases) undergoing hemodialysis. Likewise, with the Valero et al. ${ }^{18}$ study concluded that the prevalence of poor sleep quality is prevalent among adults.

Increased prevalence of insomnia in women generally occurs at the onset of menstruation and menopause. Another reason for the existence of gender differences in insomnia is probably due to differences in the prevalence of psychiatric disorders, symptom support, gonadal steroids, socio-cultural factors, and coping strategies ${ }^{19,20}$. Another reason for the existence of gender differences in insomnia is probably due to differences in the prevalence of psychiatric disorders, symptom support, gonadal steroids, socio-cultural factors, and coping strategies ${ }^{20}$.
The mean insomnia score after intervention in both groups was significantly lower than before (Table 2). The results also showed that the mean change in insomnia score before and after intervention in the experimental group was significantly lower than that in the control group $(P<0.05)$ (Table 3$)$.
The level of education, employment, and marital status are also one of the socio-cultural factors that can affect insomnia. A high level of education can enable individuals to access and understand information about health so that patients have the knowledge to choose strategies to overcome insomnia. Also, wife/husband/

\section{Discussion}

Some studies showed that insomnia is more common in the elderly ${ }^{15}$. The cause for an increased risk of insomnia

Table 3. Distribution of the average score of insomnia after the intervention between the control and intervention groups $(n=50)$.

\begin{tabular}{|c|c|c|c|c|c|c|}
\hline Variable & Group & Mean & SD & SE & p-Value & n \\
\hline \multirow{2}{*}{ Insomnia } & Controls & 10.12 & 3.811 & 0.865 & 0.039 & 25 \\
\cline { 2 - 7 } & Interventions & 7.68 & 4.318 & 1.084 & & 25 \\
\hline
\end{tabular}


family support for patients can also reduce anxiety levels which is one of the factors that is positively correlated with the incidence of insomnia in hemodialysis patients.

The results of analysis showed, after the intervention, there was a significant difference in the average insomnia score between before and after the intervention in the control group ( $p$-value $=0.001$ ), as well as in the intervention group there were significant differences in the average insomnia score between before and after the intervention ( $p$-value $=0.000$ ).

If seen insomnia scores after the intervention, both groups experienced a decrease, but the intervention group who did PMR and received aromatherapy experienced a greater insomnia score reduction than the control group who only did PMR exercise. The intervention group after PMR and aromatherapy therapy showed an average reduction in insomnia scores of 7.72 points, while the control group had a 2.4 point decrease. The results of the further analysis showed that there were significant differences in the average insomnia score after the intervention between the control group and the intervention group ( $p$-value $=0.039$ ).

The results of this study indicate that PMR exercises can reduce insomnia in hemodialysis patients, likewise, if PMR is given in conjunction with aromatherapy interventions it can have a better effect in reducing insomnia complaints in hemodialysis patients. These results support the results of previous studies, which concluded that PMR has a beneficial impact on the quality of sleep of patients undergoing hemodialysis and can be applied and trained as a useful method in improving the sleep quality of hemodialysis' patients ${ }^{10}$. Likewise, Shamsikhani's research found that the average insomnia score of hemodialysis patients decreased after progressive muscle relaxation (PMR) was performed ${ }^{22}$. Other studies also prove that PMR is quite effective in overcoming other problems, such as anxiety, psychosocial distress, fatigue, and pain that can directly or indirectly affect sleep quality so that the study concluded that PMR has effectiveness in improving the quality of patients' sleep ${ }^{23,24}$.

PMR is a method to help reduce muscle tension so that the body relaxes. The purpose of this relaxation exercise is to produce responses that can combat stress responses. The benefits of PMR are reducing anxiety, body oxygen consumption, metabolic rate, breathing frequency, muscle tension, systolic blood pressure, and diastole, premature ventricular contractions, and increased brain alpha waves ${ }^{25}$. Physiologically, stressful situations activate the hypothalamus which further controls two neuroendocrine systems, namely the sympathetic system and the adrenal cortex system. The sympathetic nervous system responds to nerve impulses from the hypothalamus by activating various organs and smooth muscles under its control, for example, it increases heart rate, increases blood pressure, increases blood flow to muscles and dilates pupils ${ }^{26}$.

The sympathetic nervous system also signals the adrenal medulla to release epinephrine and norepinephrine into the bloodstream. The adrenal cortex system is activated if the hypothalamus secretes corticotropin-releasing hormone (CRH), a chemical that acts on the pituitary gland located just below the hypothalamus. The pituitary gland then secretes the adrenocorticotropic hormone (ACTH), which is carried through the bloodstream to the adrenal cortex. The ACTH hormone then stimulates the release of a group of hormones, including cortisol, which regulates blood sugar levels. ACTH also signals other endocrine glands to release about 30 hormones. The combined effects of various stress hormones carried through the bloodstream plus the neural activity of the sympathetic branch of the autonomic nervous system play a role in the fight or flight response ${ }^{27}$.

Response fight or flight is a reaction to stress in the body which includes increased heart rate, respiration, blood pressure, and serum cholesterol. The philosophy of the fight or flight response is when faced with a threat, the body prepares itself to stay in the place of facing the threat (fight) or will run away from the threat (flight). Smeltzer \& Bare $^{26}$ said the purpose of relaxation exercises is to produce responses that can combat stress. Thus, when performing progressive muscle relaxations calmly, relaxed and full of concentration (deep relaxation) of tense and muscle relaxation that is trained for 30 minutes, the secretion of CRH and ACTH in the hypothalamus decreases. It can thus help reduce the physiological and cognitive states of stimuli that interfere with sleep, thereby facilitating functional pre-sleep processes characterized by cognitive and physiological deactivation ${ }^{28}$.

Besides to PMR, the use of aromatherapy as a therapy in overcoming the problem of insomnia has been done and the results show that aromatherapy is quite effective in improving the quality of sleep of patients. There are three ways in which essential oils can be absorbed into the human body : through the respiratory system (inhalation); transdermally via direct contact; 
and oral ingestion. Aromatherapy inhalation causes a rapid and effective effect that can induce a central nervous system response in just four seconds. Aromatherapy inhalation activity begins with the absorption of volatile molecules through the nasal mucosa, then volatile molecules enter the circulatory system after gas exchange to the lungs ${ }^{29}$. After inhaled by the patients, aroma molecules could be transferred to the limbic system in the brain to the olfactory bulb in the nose. Furthermore, the limbic system interacts with the cerebral cortex to produce relaxation and sedative effect that could promote sleep ${ }^{30}$. Moeini et al. ${ }^{31}$ studied the effects of aromatherapy with lavender on the sleep quality of patients with ischemic heart disease, and the results showed that the sleep quality score of patients experienced a significant improvement after aromatherapy intervention. Likewise, the research of Nasiri \& Fahimzade ${ }^{11}$ found that aromatherapy can improve patients' sleep quality. In line with this study, Chien et al. ${ }^{12}$ also concluded that lavender aromatherapy can improve the sleep quality of middle-aged women who experience insomnia.

Specifically, research on the effects of aromatherapy on the sleep quality of HD patients also shows that lavender aromatherapy oil has a positive effect in improving the sleep quality of HD patients ${ }^{32}$. Lavender has been suggested as an excellent natural remedy for treating insomnia and improving sleep quality. Lavender is also thought to have a variety of therapeutic and curative properties, ranging from relaxing to treating parasitic infections, burns, insect bites, and seizures. There is increasing evidence that lavender oil may be an effective drug in treating several neurological disorders ${ }^{33}$.

The effect of lavender aromatherapy oil on improving sleep quality can be associated with stimulation of neurobiological changes. Neurotransmitters of different neurons can be released depending on the type of scent used. These neurotransmitters include enkephalin, endorphin, noradrenaline, and serotonin which function in regulating stress, lowering blood pressure, providing a reward system (giving pleasure) in the brain and mood and suppressing pain ${ }^{34}$. Lavender essential oils mainly include linalool and linalyl acetate. It has been reported that low-dose linalool has a sedative effect on the human body by steam inhalation Linalool in lavender can prevent the release of acetylcholine and change the function of ion channels at the neuromuscular attachment site. Besides, linalool acetate has a narcotic function and acts as a sedative.
Rosdiana's research ${ }^{35}$ found that anxiety is the most dominant factor in the incidence of insomnia, so interventions aimed at overcoming anxiety, such as the administration of aromatherapy, can overcome insomnia, which in turn can improve the patient's sleep quality. Likewise, pain is thought to often cause insomnia, so PMR and aromatherapy interventions to overcome pain can ultimately improve the patient's sleep quality.

The limitation of this study is that the intervention procedure is carried out at home so that the researcher cannot control the intervention procedure. The efforts made by researchers to ensure the effectiveness of the intervention were to train respondents to carry out the PMR procedure until the patient was able to do it himself, providing procedure pamphlets and observation sheets to monitoring implementations.

From the results of our study, we can affirm that there was a significant decrease in the average insomnia score in the control group after PMR intervention ( $p$-value $=0.001)$. Likewise in the intervention group, there was a significant decrease in the average insomnia score after PMR and aromatherapy intervention ( $p$-value $<0.001$ ). The results of the further analysis show that the administration of PMR interventions combined with aromatherapy causes a significantly lower insomnia score than a single PMR intervention ( $p$-value $=0.039)$, so it can be concluded that the use of the two therapies simultaneously can have a greater effect in overcoming insomnia HD patient. This study recommends that the use of $\mathrm{PMR}$ and aromatherapy can be one of the nursing interventions in treating insomnia in hemodialysis.

\begin{tabular}{|l|}
\hline Recepción: $23-06-20$ \\
Aceptación: 15-12-20 \\
Publicación: $30-03-21$
\end{tabular}

\section{Bibliografía}

1. Al-Jahdali HH, Khogeer HA, Al-Qadhi WA, Baharoon S, Tamim H, Al-Hejaili F F, Al-Ghamdi $S M, A l-S a y y a r i$ AA. Insomnia in chronic renal patients on dialysis in Saudi Arabia. J Circadian Rhythms. 2010 Jun;8(1):7. 
2. Sabbatini $M$, Minale $B$, Crispo $A$, Pisani $A$, Ragosta $A$, Esposito R, Cesaro A, Cianciaruso B, Andreucci VE. Insomnia in maintenance haemodialysis patients. Nephrol Dial Transplant. 2002 May;17(5):852-6.

3. International Classification of Sleep Disorders. Diagnostic and Coding Manual. American Academy Sleep Medicine. 2005;51-55.

4. Szentkiralyi A, Madarasz CZ, Novak M. Sleep Disorders: Impact on Daytime Functioning and Quality of Life. Res. Expert Rev Pharmacoecon Outcomes Res. 2009 Feb;9(1):49-64.

5. Novak M, Shapiro CM, Mendelssohn DM. Diagnosis and Management of Insomnia in Dialysis Patients. Semin Dial. 2006 Jan-Feb;19(1):25-31.

6. Elder SJ, Pisoni RL, Akizawa T, Fissell R, Andreucci VE, Fukuhara S, Kurokawa K, Rayner HC, Furniss $A L$, Port FK, Saran R. Sleep quality predict quality of life and mortality risk in haemodialysis patients: Results from the Dialysis Outcomes and Practice Patterns Study (DOPPS). Nephrol dial Transpl. 2008 Mar;23(3):998-1004.

7. Noriega, RB, Camporro S N, Rodríguez AMI. Nursing and no Drug for the Management of Insomnia Treatment. Enfermería Glob. 2019 Apr;18(2):523-32.

8. Elham A, Goudarzi I, Masoudi R, Ahmadi A, Momeni A. Effect of Progressive Muscle Relaxation and Aerobic Exercise on Anxiety, Sleep Quality, and Fatigue in Patients with Chronic Renal Failure Undergoing Hemodialysis. Int J Pharm Clin Res 2016. 2006 Dec;8(12):1634-9.

9. Saeedi M, Ashktorab T, Khani SS, Saatchi K. The Effect of Progressive Muscle Relaxation on Insomnia Severity of Hemodialysis Patients. Complement Ther Clin Pract. 2012 May;2(2):159-70.

10. Amini A., Goudarzi I, Masoudi R, Ahmadi A, Momeni A. Effect of progressive muscle relaxation and aerobic exercise on anxiety, sleep quality, and fatigue in patients with chronic renal failure undergoing hemodialysis. Int $\mathrm{J}$ Pharm Clin Res. 2016;8(12):1634-9.

11. Nasiri A, Fahimzade L. The Effect of Inhalation Aromatherapy with Lavender on Sleep Quality of the Elderly in Nursing Care Homes: A Randomized Clinical Trial, Modern Care Journal, In Press. 2017;14(4):e6602.

12. Chien WL, Cheng SL, Liu CF. The Effect of Lavender Aromatherapy on Autonomic Nervous System in Midlife Women with Insomnia. Evidence-Based Complement Alternative Med. 2012. Available from: https://doi.org/10.1155/2012/740813.

13. Veqar $Z$, Hussain ME. Validity and reliability of insomnia severity index and its correlation with pittsburgh sleep quality index in poor sleepers among Indian university students. Int $\mathrm{J}$ Adolesc Med Health. 2017 Jan;32(1).

14. Morin CM, Bellevile G, Belanger L, Ivers H. The insomnisa severity index: psychometric indicators to detect insomnia cases and evaluated treatment response. Sleep. 2011 May;34(5):601-8.

15. Patel $D$, Steinberg J, Patel P. Insomnia in the elderly: a review. J Clin Sleep Med. 2018 Jun; 14(6):1017-24.

16. Roth T. Insomnia: definition, prevalence, etiology, and consequences. J Clin Sleep Med. 2007 Aug; 3(5):7.

17. Merlino G, Piani A, Dolso P, Adorati M, Cancelli I, Valente M. Sleep disorders in patients with end-stage renal disease undergoing dialysis therapy. Nephrol Dial Transplant. 2006 Jan; 21(1):184-90.

18. Valero M, Martínez-Selva JM, Couto BR. D., Sánchez-Romera JF, Ordoñana JR. Age and gender effects on the prevalence of poor sleep quality in the adult population. Gac Sanit. 2017 Jan-Feb; $31(1): 18-22$.

19. Modjod D. Insomnia experience, management strategies, and outcomes in ESRD patients undergoing hemodialysis. (Doctoral dissertation, Mahidol University). 2007.

20. Li RHY, Wing YK, Ho SC, Fong SYY. Gender differences in insomnia - a study in the Hong Kong Chinese population. J Psychosom Res. 2002 Jul; 53(1):601-9.

21. Hou $Y$, Hu P, Liang Y, Mo Z. Effects of cognitive behavioral therapy on insomnia of maintenance hemodialysis patients. Cell Biochem Biophys. 2014 Jul;69(3):531-7. 
22. Shamsikhani S. The effect of progressive muscle relaxation on insomnia severity of hemodialysis patients. Complement Med J Fac Nurs Midwifery. 2012;2(2):159-70.

23. Yildirim YK, Fadiloglu C. The effect of progressive muscle relaxation training on anxiety levels and quality of life in dialysis patients. EDNAT ERCA J. 2006 Apr-Jun;32(2):86-8.

24. Rosdiana I, Cahyati Y. Effect of Progressive Muscle Relaxation (PMR) on Blood Pressure among Patients with Hypertension. 2019;2(1):28-35.

25. Lindquist R, Snyder M, Tracy MF. Complementary Alternative Therapies in Nursing. 7th ed. New York: Springer Publishing Company; 2002.

26. Smeltzer SC, Bare BG, Hinkle JL. Brunner \& Suddarth's Textbook of medical-surgical nursing. 11 th ed. Philadelphia: Lippincott William \& Wilkins; 2010.

27. Ramsey AA, Rolnick K, Smith R, Weng C, Li $Y$, Lokuta A. Activation of the Human Sympathetic Nervous System : Effects on Memory Performance. Journal of Advanced Student Science, 2012; 1.

28. Yousefi S, Taraghi Z, Mousavinasab N. The Effect of Progressive Muscle Relaxation (PMR) on Sleep Quality in Patients With Chronic Heart Failure (CHF).

29. Valnet C. Essential oils \& Aromatherapy. Edizioni REI France. 2015.
30. Woronuk G, Demissie Z, Rheault M, Mahmoud $S$. Biosynthesis and therapeutic properties of Lavandula essential oil constituents. Planta Med. 2011 Jan;77(1):7-15.

31. Moeini M, Khadibi M, Bekhradi R, Mahmoudia, S A, \& Nazari F. Effect of aromatherapy on the quality of sleep in ischemic heart disease patients hospitalized in intensive care units of heart hospitals of the Isfahan University of Medical Sciences. Iran J Nurs Midwifery Res. 2010;15(4):234.

32. Najafi Z, Tagharrobi Z, \& Shahriyari-Kale-Masihi M. Effect of aromatherapy with Lavender on sleep quality among patients undergoing hemodialysis. KAUMS J FEYZ. 2014; 8(2):145-50.

33. Koulivand PH, Khaleghi GM, Gorji A. Lavender and the nervous system. Evid Based Complement Alternat Med. 2013;681304.

34. François A, Low SA, Sypek EI, Christensen AJ, Sotoudeh C, Beier KT, et al. A Brainstem-Spinal Cord Inhibitory Circuit for Mechanical Pain Modulation by GABA and Enkephalins. Neuron. 2017 Feb 22;93(4):822-39.

35. Rosdiana I, Yetty K, Sabri L. Kecemasan dan Lamanya Waktu Menjalani Hemodialisis Berhubungan dengan Kejadian Insomnia pada Pasien Gagal Ginjal Kronik. J Keperawatan Indonesia. 2014;17(2):39-47.

Este artículo se distribuye bajo una Licencia Creative Commons Atribución-NoComercial 4.0 Internacional. https://creativecommons.org/licenses/by-nc/4.0/ 